\title{
Theoretical and practical methodology for recognizing the road surface structure
}

\author{
Stefan Firlej, Marcin Dębiński
}

\author{
Lublin University of Technology, Faculty of Civil Engineering and Architecture, \\ Department of Roads and Bridges, Nadbystrzycka 40,20-618 Lublin, e-mail: m.debinski@pollub.pl
}

\begin{abstract}
A recognition indicator of the possibility of further use of the road during transferring transport loads are changes in the condition of the road surface. If the surface condition indicates incorrect parameters of its equality, rutting, or cracks, the road durability is qualitatively assessed. In this case, the actual load capacity rating and possible reconstruction of the structure begins. Values of dynamic deflections can be used to recognize the modulus of elasticity and thus the possibility of assessing the durability of a structure. The mechanistic method is used to dimensioning the structure due to the movement planned. It allows a flexible approach to further construction, giving the opportunity to assess whether part or all of it should be left or apply an additional layer to meet future requirements. The elastic modulus needed for this pavement structure design method for existing layers has been recognized by identification as backcalculation methodology that have been used for many years.
\end{abstract}

Keywords: road surface, backcalculation, dynamic deflections, road durability.

\section{Introduction}

In recent years, the road network in Poland has been significantly expanded. Many kilometers of roads have been created. The development of the car transport and the increase in the number of vehicles on Polish roads will result in the need for maintenance and repair. Appropriate recognition of the surface condition enables an adequate assessment of the structure and a decision as to the type of a repair method. In order to compare the practical and theoretical methods of a structure recognition, research and analysis were performed using two methods. The practical method chosen for the study is the Falling Weight Deflectometer (FWD) dynamic deflectometer test and the theoretical method - by means of backcalculation methodology [1-2].

\section{Results}

\subsection{Backcalculation method}

The analysis of the implementation of the backcalculation methodology as the surface identification was carried out for 2-, 3- and 4-layer systems. Calculations of the elastic deflections were made with the strictly theoretical method according to the theory of the cylindrical layout of the structure. The center of the wheel load of the computational car was adopted as its center. The model with 5 or more layers was omitted due to the solution being too long even in a computerized approach. These models were loaded with a car wheel with a diameter of 
$30 \mathrm{~cm}$ and a road pressure of $0.707 \mathrm{MPa}$. The lowest layer in this case is of infinite thickness. The numbering of the layers has been taken from the bottom to the top, in which the lowest is 1 , and the highest number is related to the number of layers.

\subsubsection{Two-layer model}

The construction of the model is shown in the figure below.

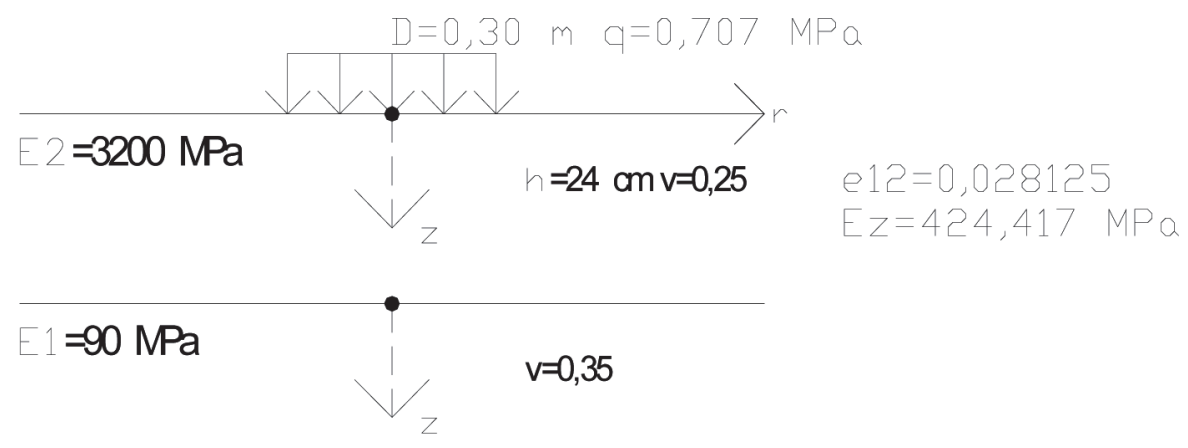

Fig. 1. 2-layer model

Fig. 1. 2-layer model

Computational vertical displacements of the road surface loaded from the center every $30 \mathrm{~cm}$ with an accuracy of $10^{-3}$ micrometers.

Table 1. List of deflections of the 2-layer model

\begin{tabular}{ccc}
\hline $\mathrm{I}$ & ri $[\mathrm{cm}]$ & $\mathrm{w}[\mu \mathrm{m}]$ \\
\hline 0 & 0 & 438.525 \\
\hline 1 & 30 & 342.773 \\
\hline 2 & 60 & 254.289 \\
\hline 3 & 90 & 187.33 \\
\hline 4 & 120 & 140.68 \\
\hline 5 & 150 & 109.237 \\
\hline 6 & 180 & 88.117 \\
\hline
\end{tabular}

The backcalculation methodology is the determination of the modulus of elasticity of the model layers based on deflections and other parameters such as the layer thickness, load, and Poisson's coefficients. The method of determination in the normal case would be a longer, 2-layer, equal to 2 unknowns. To shorten the calculations, the methodology was changed from the 2 to 1 of the unknown. Instead of the modules, their quotient E1/E2 was assumed in relation to the wi/wo deflection quotient. The successive changes of the E1/E2 value and the calculation of the quotient of appropriate deflections for the changing model lead to the determination of the correct quotient of the modules. Using the back-calculating method, models for the basis point and subsequent points were calculated. The assumed deflection value with an accuracy of $1 \mu \mathrm{m}$ and $0.001 \mu \mathrm{m}$ indicates how different the elasticity modules 
are. Leaving them gives the answer how exactly deflections should be measured using the FWD and Heavy Weight Deflectometer HWD [3-4].

Table 2. Identification results for an accuracy of $1 \mu \mathrm{m}$

\begin{tabular}{cccccccccccc}
\hline $\mathrm{i}$ & $\begin{array}{c}\text { wo } \\
{[\mu \mathrm{m}]}\end{array}$ & $\begin{array}{c}\text { wi } \\
{[\mu \mathrm{m}]}\end{array}$ & $\begin{array}{c}\mathrm{E} 1 \\
{[\mathrm{MPa}]}\end{array}$ & $\begin{array}{c}\mathrm{E} 2 \\
{[\mathrm{MPa}]}\end{array}$ & \multicolumn{6}{c}{ Set of computational deflections for i, $[\mu \mathrm{m}]$} \\
\hline $0-1$ & 439 & 343 & 90.01 & 3189.9 & 439 & 343 & 254.36 & 187.327 & 140.652 & 109.209 & 88.096 \\
\hline $0-2$ & 439 & 254 & 90.19 & 3178.24 & 439 & 342.746 & 254 & 289.966 & 140.337 & 108.952 & 87.89 \\
\hline $0-3$ & 439 & 187 & 90.17 & 3179.35 & 439 & 342.77 & 254.034 & 187 & 140.367 & 108.996 & 87.909 \\
\hline $0-4$ & 439 & 141 & 89.81 & 3202.78 & 439 & 343.279 & 254.756 & 187.726 & 141 & 109.493 & 883.23 \\
\hline $0-5$ & 439 & 109 & 90.16 & 3180.44 & 439 & 342.794 & 254.068 & 187.034 & 140.397 & 109 & 87.929 \\
\hline $0-6$ & 439 & 88 & 90.09 & 3184.48 & 439 & 342.882 & 254.192 & 187.159 & 140.506 & 109.089 & 88 \\
\hline $1-4$ & 343 & 141 & 89.82 & 3213.04 & 438.468 & 343 & 254.642 & 187.694 & 141 & 109.506 & 88.327 \\
\hline
\end{tabular}

Table 3. Identification results for an accuracy of $0,001 \mu \mathrm{m}$

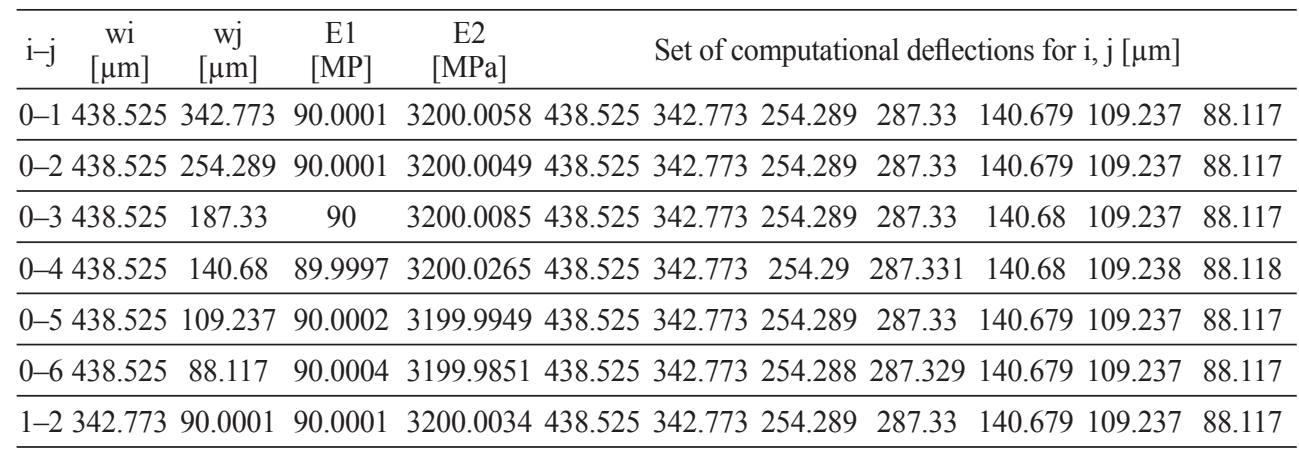

\subsubsection{Three-layer model}

The model data as in Fig. 2 was used for the analysis.

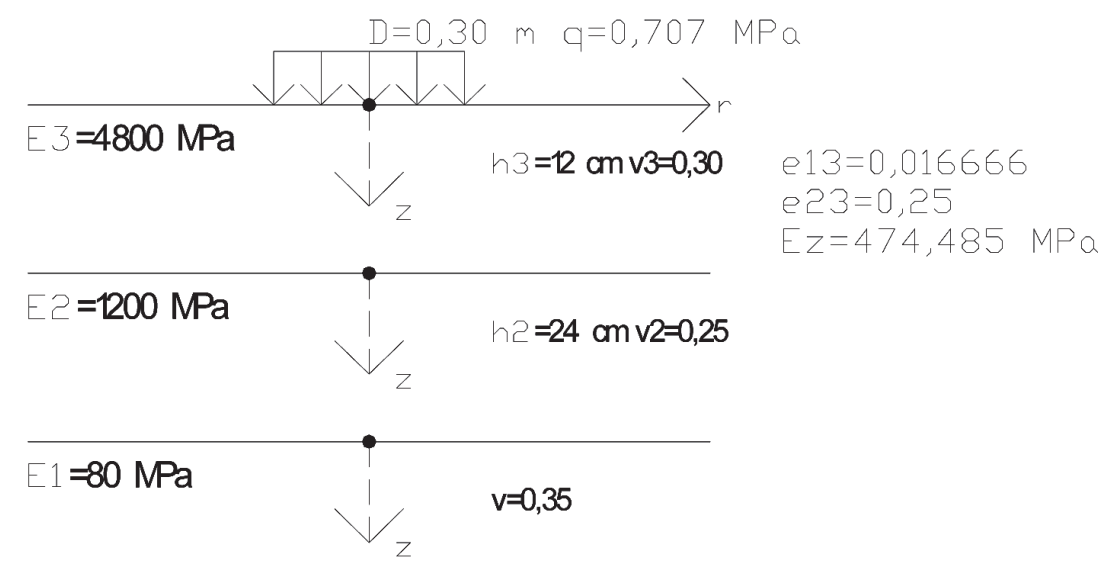

Fig. 2. 3-layer model 
The method of the backcalculation of this model comes to establishing the ratio of $w_{i} / w_{o}$ and $w_{j} / w_{o}$ deflections quotients for the changing $e_{13}$ and $e_{23}$ quotients, so that the deflections of the searched and known model are consistent. The search function (1) and (2) is dependent respectively on (3) and (4). After determining the values of the $e_{13}$ and $e_{23}$ quotients, the values of the $E_{1}, E_{2}$, and $E_{3}$ modules are determined.

$$
\begin{aligned}
& w_{i} / w_{o}=w_{i o} \\
& w_{j} / w_{o}=w_{j o} \\
& E_{1} / E_{2}=e_{13} \\
& E_{2} / E_{3}=e_{23}
\end{aligned}
$$

Table 4. List of deflections of the 3-layer model

\begin{tabular}{ccc}
\hline $\mathrm{I}$ & $\mathrm{ri}[\mathrm{cm}]$ & $\mathrm{w}[\mu \mathrm{m}]$ \\
\hline 0 & 0 & 392.252 \\
\hline 1 & 30 & 309.923 \\
\hline 2 & 60 & 243.205 \\
\hline 3 & 90 & 192.553 \\
\hline 4 & 120 & 153.797 \\
\hline 5 & 150 & 124.617 \\
\hline 6 & 180 & 102.825 \\
\hline
\end{tabular}

Table 5. Identification results for the model at the value of rounded deflections

\begin{tabular}{ccccccccccccc}
\hline $\mathrm{I}$ & $\mathrm{j}$ & $\mathrm{k}$ & $\mathrm{E} 1[\mathrm{MPa}]$ & $\mathrm{E} 2[\mathrm{MPa}]$ & $\mathrm{E} 3[\mathrm{MPa}]$ & \multicolumn{5}{c}{ Set of computational deflections for $\mathrm{i}, \mathrm{j}, \mathrm{k}[\mu \mathrm{m}]$} \\
\hline 0 & 1 & 2 & 80.09 & 1177.38 & 4951.79 & 392 & 310 & 243 & 192 & 153 & 124 & 103 \\
\hline 0 & 1 & 3 & 79.77 & 1212.96 & 4790.74 & 392 & 310 & 244 & 193 & 154 & 125 & 103 \\
\hline 0 & 1 & 4 & 79.88 & 1200.52 & 4846.02 & 392 & 310 & 243 & 193 & 154 & 125 & 103 \\
\hline 0 & 1 & 5 & 79.78 & 1211.41 & 4797.61 & 392 & 310 & 244 & 193 & 154 & 125 & 103 \\
\hline 0 & 1 & 6 & 79.87 & 1200.83 & 4844.66 & 392 & 310 & 243 & 193 & 154 & 125 & 103 \\
\hline 0 & 2 & 3 & 80.13 & 1388.77 & 3799.67 & 392 & 307 & 243 & 193 & 154 & 125 & 103 \\
\hline 0 & 2 & 4 & 80.07 & 1280.82 & 4321.78 & 392 & 309 & 243 & 193 & 154 & 125 & 103 \\
\hline 0 & 2 & 5 & 80.11 & 1359.61 & 3928.77 & 392 & 308 & 243 & 193 & 154 & 125 & 103 \\
\hline 0 & 2 & 6 & 80.08 & 1304.66 & 4195.68 & 392 & 308 & 243 & 193 & 154 & 125 & 103 \\
\hline 0 & 3 & 4 & 97.52 & 1050.26 & 6186.66 & 392 & 313 & 244 & 193 & 154 & 125 & 103 \\
\hline 0 & 3 & 5 & 97.71 & 1182.53 & 5009.53 & 392 & 311 & 244 & 193 & 154 & 125 & 103 \\
\hline 0 & 3 & 6 & 79.52 & 1049.32 & 6178.17 & 392 & 313 & 244 & 193 & 154 & 125 & 103 \\
\hline 0 & 4 & 5 & 82.18 & 522.37 & 930.83 & 392 & 281 & 235 & 191 & 154 & 125 & 103 \\
\hline 0 & 4 & 6 & 82.13 & 5602.52 & 883.87 & 392 & 279 & 234 & 190 & 154 & 125 & 103 \\
\hline
\end{tabular}


Table 6. Identification results for $10^{-3} \mu \mathrm{m}$ bottom layers

\begin{tabular}{|c|c|c|c|c|c|c|c|c|c|c|c|c|}
\hline I & $\mathrm{j}$ & $\mathrm{k}$ & $\begin{array}{c}\mathrm{E} 1 \\
{[\mathrm{MPa}]}\end{array}$ & $\begin{array}{c}\mathrm{E} 2 \\
{[\mathrm{MPa}]}\end{array}$ & $\begin{array}{c}\text { E3 } \\
{[\mathrm{MPa}]}\end{array}$ & \multicolumn{7}{|c|}{ Set of computational deflections for $\mathrm{i}, \mathrm{j}, \mathrm{k}[\mu \mathrm{m}]$} \\
\hline 0 & 1 & 2 & 80 & 1200.06 & 4799.61 & 392.252 & 309.923 & 243.205 & 192.553 & 153.797 & 124.617 & 102.825 \\
\hline 0 & 1 & 3 & 80 & 1200.06 & 4799.62 & 392.252 & 309.922 & 243.205 & 192.553 & 153.797 & 124.617 & 102.825 \\
\hline 0 & 1 & 4 & 80 & 1200.05 & 4799.63 & 392.252 & 309.922 & 243.205 & 192.553 & 153.797 & 124.617 & 102.825 \\
\hline 0 & 1 & 5 & 80 & 1200.05 & 4799.62 & 392.252 & 309.922 & 243.205 & 192.523 & 153.797 & 124.617 & 102.825 \\
\hline 0 & 1 & 6 & 80 & 1200.01 & 4799.91 & 252 & 923 & 205 & 523 & 797 & 617 & 825 \\
\hline 0 & 2 & 3 & 80 & 1200.01 & 4799.62 & 252 & 922 & 205 & 553 & 797 & 617 & 825 \\
\hline 0 & 2 & 4 & 80 & 1199.97 & 4800.19 & 252 & 924 & 205 & 553 & 797 & 617 & 825 \\
\hline 0 & 2 & 5 & 80 & 1199.99 & 4800.07 & 252 & 923 & 205 & 553 & 797 & 617 & 825 \\
\hline 0 & 2 & 6 & 80 & 1199.95 & 4801.31 & 252 & 924 & 205 & 553 & 797 & 617 & 825 \\
\hline 0 & 3 & 4 & 79.99 & 1199.73 & 4801.91 & 252 & 925 & 206 & 553 & 797 & 617 & 825 \\
\hline 0 & 3 & 5 & 80 & 1199.82 & 4801.23 & 252 & 926 & 206 & 553 & 797 & 617 & 825 \\
\hline 0 & 3 & 6 & 80 & 1199.25 & 4805.29 & 252 & 936 & 208 & 553 & 797 & 617 & 825 \\
\hline 0 & 4 & 5 & 80 & 1199.97 & 4800.18 & 252 & 924 & 205 & 553 & 797 & 617 & 825 \\
\hline 0 & 4 & 6 & 80 & 1199.97 & 4800.19 & 252 & 924 & 205 & 553 & 797 & 617 & 825 \\
\hline 0 & 5 & 6 & 80 & 1199.97 & 4800.19 & 252 & 924 & 205 & 553 & 797 & 617 & 825 \\
\hline
\end{tabular}

\subsubsection{Four-layer model}

The analysis of the model was carried out for the data shown in Fig. 3.

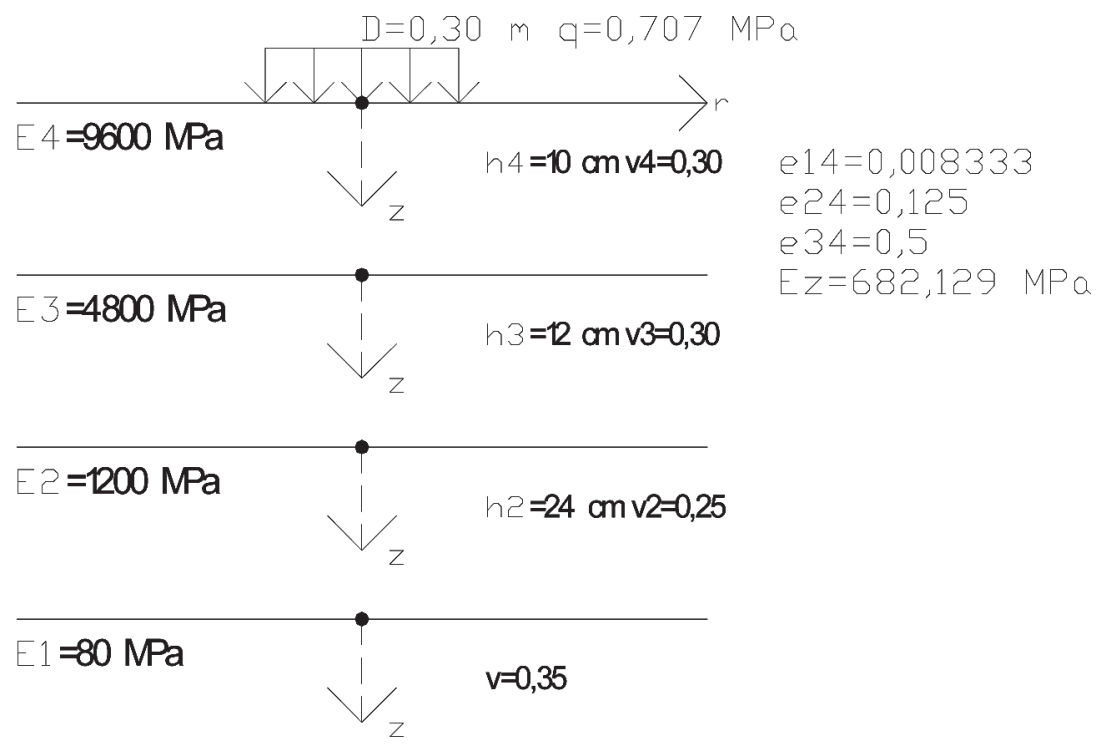

Fig. 3. 4-layer model 
Table 7. Deflections in the 4-layer model

\begin{tabular}{ccc}
\hline$I$ & $r_{i}[\mathrm{~cm}]$ & $w[\mu \mathrm{m}]$ \\
\hline 0 & 0 & 272.848 \\
\hline 1 & 30 & 233.536 \\
\hline 2 & 60 & 198.366 \\
\hline 3 & 90 & 168.342 \\
\hline 4 & 120 & 142.713 \\
\hline 5 & 150 & 121.255 \\
\hline 6 & 180 & 103.563 \\
\hline
\end{tabular}

Identification of the 4-layer model on the basis of deflections calculated was carried out similarly to the previous one. The (5),(6),(7) modulus quotients were successively changed for the remaining data to obtain for these theoretical models the deflections quotients. If the deflections quotients matched with the quotients of the corresponding known values from Table 7 the (8),(9),(10) function and the modules quotients were obtained. The modules of the searched model were obtained on the basis of the quotients of the modules and the $E_{z}$ replacement module. The list of identification (back-calculating) for deflections from below to $1 \mu \mathrm{m}$ is given in Tab. 8

$$
\begin{aligned}
& e_{14}=E_{1} / E_{4} \\
& e_{24}=E_{2} / E_{4} \\
& e_{34}=E_{3} / E_{4} \\
& w_{i} / w_{o}=w_{i o} \\
& w_{j} / w_{o}=w_{j o} \\
& w_{k} / w_{o}=w_{k o}
\end{aligned}
$$

Table 8. Identification results for an accuracy of $1 \mu \mathrm{m}$

\begin{tabular}{ccccccccccccccc}
\hline $\mathrm{i}$ & $\mathrm{j}$ & $\mathrm{k}$ & 1 & $\begin{array}{c}\mathrm{E} 1 \\
{[\mathrm{MPa}]}\end{array}$ & $\begin{array}{c}\mathrm{E} 2 \\
{[\mathrm{MPa}]}\end{array}$ & $\begin{array}{c}\mathrm{E} 3 \\
{[\mathrm{MPa}]}\end{array}$ & $\begin{array}{c}\mathrm{E} 4 \\
{[\mathrm{MPa}]}\end{array}$ & \multicolumn{3}{c}{ Set of computational deflections for i,j, $\mathrm{k}, 1[\mu \mathrm{m}]$} \\
\hline 0 & 1 & 2 & 3 & 79.42 & 1117.92 & 3732.09 & 13350.38 & 273 & 234 & 198 & 168 & 142.572 & 121.321 & 103.794 \\
\hline 0 & 1 & 2 & 4 & 78.83 & 1142.52 & 3386.73 & 14514.64 & 273 & 234 & 198 & 168.231 & 143 & 121.875 & 104.415 \\
\hline 0 & 1 & 2 & 5 & 79.76 & 1106.19 & 3946.78 & 12692.9 & 273 & 234 & 198 & 167.868 & 142.326 & 121 & 103.437 \\
\hline 0 & 1 & 2 & 6 & 79.22 & 1125.61 & 3612.64 & 13737.32 & 273 & 234 & 198 & 168.078 & 142.715 & 121.504 & 104 \\
\hline 0 & 1 & 3 & 4 & 78.35 & 1156.66 & 2820.67 & 17148.8 & 273 & 234 & 197.605 & 168 & 143 & 122.069 & 104.742 \\
\hline 0 & 1 & 3 & 5 & 79.89 & 1115.5 & 4203.94 & 11824.66 & 273 & 234 & 198.168 & 168 & 142.389 & 121 & 103.39 \\
\hline 0 & 1 & 3 & 6 & 79.18 & 1122.6 & 3509.98 & 14169.13 & 273 & 234 & 197.913 & 168 & 142.665 & 121.483 & 104 \\
\hline
\end{tabular}




\begin{tabular}{ccccccccccccccc}
\hline $\mathrm{i}$ & $\mathrm{j}$ & $\mathrm{k}$ & 1 & $\begin{array}{c}\mathrm{E} 1 \\
{[\mathrm{MPa}]}\end{array}$ & $\begin{array}{c}\mathrm{E} 2 \\
{[\mathrm{MPa}]}\end{array}$ & $\begin{array}{c}\mathrm{E} 3 \\
{[\mathrm{MPa}]}\end{array}$ & $\begin{array}{c}\mathrm{E} 4 \\
{[\mathrm{MPa}]}\end{array}$ & \multicolumn{5}{c}{ Set of computational deflections for i,j, $\mathrm{k}, 1[\mu \mathrm{m}]$} \\
\hline 0 & 1 & 4 & 5 & 80.98 & 1343.29 & 8860.74 & 5561.39 & 273 & 234 & 199.812 & 169.284 & 143 & 121 & 102.936 \\
\hline 0 & 1 & 4 & 6 & 79.46 & 1155.25 & 4258.67 & 11398.27 & 273 & 234 & 198.502 & 168.524 & 143 & 121.631 & 104 \\
\hline 0 & 1 & 5 & 6 & 78.41 & 1181.12 & 1804.14 & 24040.85 & 273 & 234 & 196.027 & 166.285 & 141.571 & 121 & 104 \\
\hline 0 & 2 & 3 & 4 & 77.68 & 1108.69 & 1967.22 & 26224.36 & 273 & 235.706 & 198 & 168 & 143 & 122.175 & 104.966 \\
\hline 0 & 2 & 4 & 6 & 79.81 & 1332.98 & 4706.59 & 8406.83 & 273 & 232.6 & 198 & 168.394 & 143 & 121.653 & 104 \\
\hline 0 & 3 & 4 & 6 & 80.62 & 2088.05 & 7127.71 & 3595.28 & 273 & 227.999 & 196.471 & 168 & 143 & 121.722 & 104 \\
\hline
\end{tabular}

Similarly, the backcalculation methodology was performed for some combinations of deflections, but with their accuracy up to $0.001 \mu \mathrm{m}$. The identification results obtained are presented in Table 9. The values of the modules were given with an accuracy of $0.01 \mathrm{MPa}$, and deflections with an accuracy of $0.001 \mu \mathrm{m}$.

Table 9. Identification results for an accuracy of $0,001 \mu \mathrm{m}$

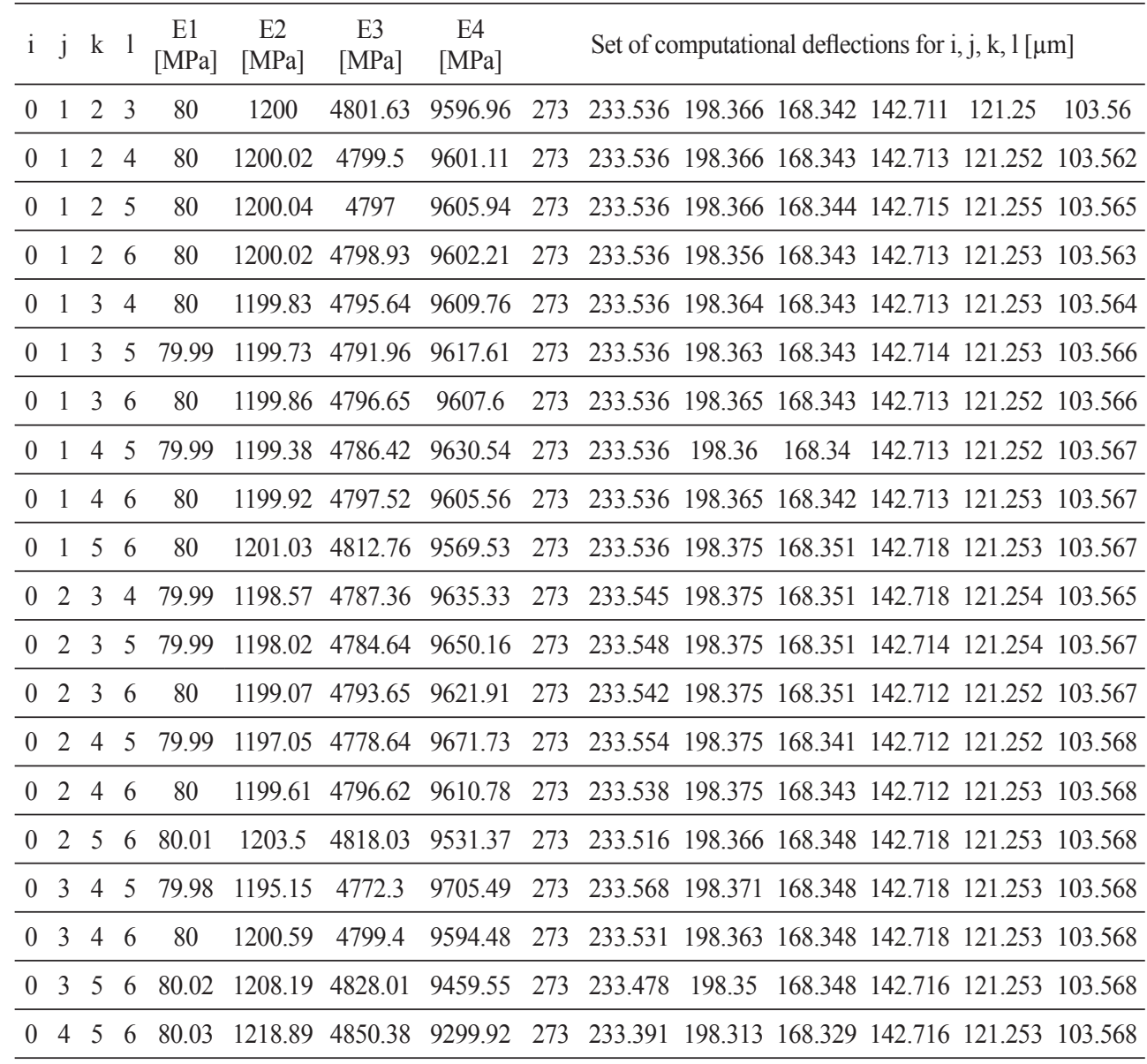


Table 10. Identification results for a set of deflections for different accuracy

\begin{tabular}{ccccccccccccc}
\hline \multirow{2}{*}{$\begin{array}{c}\text { Accuracy } \\
\end{array} \begin{array}{c}\mathrm{E} 1 \\
{[\mathrm{MPa}]}\end{array}$} & $\begin{array}{c}\mathrm{E} 2 \\
{[\mathrm{MPa}]}\end{array}$ & $\begin{array}{c}\mathrm{E} 3 \\
{[\mathrm{MPa}]}\end{array}$ & $\begin{array}{c}\mathrm{E} 4 \\
{[\mathrm{MPa}]}\end{array}$ & \multicolumn{5}{c}{ Deflections received $[\mu \mathrm{m}]$} \\
\hline $10^{-3} \mu \mathrm{m}$ & 80 & 1200 & 4801.63 & 9596.96 & 272.85 & 233.536 & 198.37 & 168.34 & 142.71 & 121.25 & 103.56 \\
\hline $10^{-2} \mu \mathrm{m}$ & 80.01 & 1199.77 & 4814.18 & 9574.79 & 272.85 & 233.54 & 198.37 & 168.34 & 142.7 & 121.24 & 103.55 \\
\hline $10^{-1} \mu \mathrm{m}$ & 80.23 & 1206.5 & 5074.82 & 9065.12 & 272.8 & 233.5 & 198.4 & 168.3 & 142.57 & 121.07 & 103.35 \\
\hline $1 \mu \mathrm{m}$ & 79.42 & 1117.92 & 3732.09 & 13350.4 & 273 & 234 & 198 & 168 & 142.57 & 121.32 & 103.79 \\
\hline
\end{tabular}

\subsection{Examples of identification on rebuilt roads}

When assessing the bearing capacity of a road undergoing reconstruction, measurements with the use of the FWD are often carried out to determine the suitability of existing layers for the new structure. In this case, the identification analysis was carried out based on the recognition of the existing surface - what are the materials in the layers, and what are the thicknesses of the layers. Materials can be determined from archival data or from the smallsized boreholes. The layer thickness can also be determined by a georadar or other possible method. In the measurement itself, the unit pressure value under the plate, the diameter of the plate, and the temperature of the test are known [5-8].

\subsubsection{Kraśnik - Janów Lubelski road DK-19 km 376+000,00 -377+200,00}

The following deflections were converted to a pressure of $0.707 \mathrm{MPa}$, so that the average values for individual geophones can be determined from the measurement set in the section.

Table 11. List of average deflections from geophones on section 1-3

\begin{tabular}{|c|c|c|c|c|c|c|c|c|}
\hline \multirow{2}{*}{ Section } & \multirow{2}{*}{ Roadway } & \multicolumn{7}{|c|}{ The average deflection under the geophone $[\mu \mathrm{m}]$} \\
\hline & & w0 & w1 & w2 & w3 & w4 & w5 & w6 \\
\hline \multirow{2}{*}{$\begin{array}{c}\text { from } 376+000,00 \\
\text { to } 376+325,00\end{array}$} & Left & 386.5 & 239.12 & 153.26 & 98.26 & 76.31 & 56.62 & 45.45 \\
\hline & Right & 475.45 & 288.41 & 184.49 & 124.18 & 88.1 & 62.66 & 49.16 \\
\hline \multirow{2}{*}{$\begin{array}{c}\text { from } 376+350,00 \\
\text { to } 376+825,00\end{array}$} & Left & 408.28 & 245.26 & 160.06 & 110.7 & 79.72 & 58.3 & 45.7 \\
\hline & Right & 444.61 & 279.67 & 185.38 & 123.1 & 89.28 & 62.82 & 48.25 \\
\hline \multirow{2}{*}{$\begin{array}{c}\text { from } 376+850,00 \\
\text { to } 377+200,00\end{array}$} & Left & 637.69 & 398.06 & 242.63 & 156.3 & 110.49 & 76.02 & 59.98 \\
\hline & Right & 574.3 & 367.22 & 221.99 & 147.11 & 104.13 & 79.08 & 64.88 \\
\hline
\end{tabular}

After converting the measurement temperature of $20^{\circ} \mathrm{C}$ to $10{ }^{\circ} \mathrm{C}$, the modules shown in Tab. 12 were received. 
Table 12. Elastic modules of the surface

\begin{tabular}{lcccccccc}
\hline \multirow{2}{*}{ Section } & \multicolumn{3}{c}{ Layer thickness [m] } & \multicolumn{3}{c}{ Poisson's ratio } & \multicolumn{3}{c}{ Layers' modules [MPa] } \\
\cline { 2 - 9 } & h3 & h2 & v3 & v2 & v1 & E3 & E2 & E1 \\
\hline from 376+000,00 to 376+325,00 & 0.185 & 0.18 & 0.3 & 0.3 & 0.3 & 1525 & 116 & 60 \\
\hline from 376+350,00 to 376+825,00 & 0.07 & 0.17 & 0.3 & 0.3 & 0.3 & 6150 & 290 & 88 \\
\hline from 376+850,00 to 377+200,00 & 0.13 & 0.17 & 0.3 & 0.3 & 0.3 & 1730 & 390 & 50 \\
\hline
\end{tabular}

Layers in this construction are:

- upper layer of the MMA surface with different composition

- middle layer - a road grit

- ground substrate made of the clay sand or clay

\subsubsection{DK 82 Lublin Włodawa road in the Lęczna km 23+670,00-24+820,00}

Table 13. The construction of the existing surface

\begin{tabular}{cccccccc}
\hline \multirow{2}{*}{ Section } & \multicolumn{3}{c}{ Layer thickness [m] } & \multicolumn{3}{c}{ Poisson's ratio } \\
\cline { 2 - 8 } & $\mathrm{h} 4$ & $\mathrm{~h} 3$ & $\mathrm{~h} 2$ & $\mathrm{v} 4$ & $\mathrm{v} 3$ & $\mathrm{v} 2$ & $\mathrm{v} 1$ \\
\hline $23+670,00$ & 0.15 & & 0.07 & 0.4 & 0.3 & 0.3 & 0.35 \\
\hline $24+100,00$ & 0.1 & 0.17 & 0.1 & 0.4 & 0.3 & 0.3 & 0.35 \\
\hline $24+600,00$ & 0.09 & 0.13 & 0.09 & 0.4 & 0.3 & 0.3 & 0.35 \\
\hline $24+700,00$ & 0.16 & 0.13 & 0.07 & 0.4 & 0.3 & 0.3 & 0.35 \\
\hline $24+820,00$ & - & 0.2 & 0.2 & - & 0.4 & 0.3 & 0.35 \\
\hline
\end{tabular}

Table 14. Reliable deflections obtained from the FWD and the identification modules

\begin{tabular}{cccccccccccc}
\hline \multirow{2}{*}{ Section } & \multicolumn{4}{c}{ The average deflection under the geophone $[\mu \mathrm{m}]$} & \multicolumn{5}{c}{ Layers' modules [MPa] } \\
\cline { 2 - 12 } & w0 & w1 & w2 & w3 & w4 & w5 & w6 & E4 & E3 & E2 & E1 \\
\hline $23+670,00$ & 626 & 390 & 230 & 142 & 96 & 69 & 54 & 1983 & 206 & 22 & 99 \\
\hline $24+100,00$ & 677 & 409 & 241 & 154 & 109 & 79 & 63 & 1593 & 465 & 33 & 139 \\
\hline $24+600,00$ & 654 & 383 & 226 & 146 & 103 & 76 & 61 & 841 & 804 & 78 & 142 \\
\hline $24+700,00$ & 571 & 360 & 227 & 148 & 104 & 74 & 61 & 720 & 884 & 32 & 106 \\
\hline $24+820,00$ & 346 & 281 & 198 & 144 & 101 & 76 & 57 & - & 2508 & 426 & 101 \\
\hline
\end{tabular}




\subsubsection{DW 815 Wisznice - Parczew - Lubartów provincial road $\mathrm{km} 27+525,00-37+225,00$}

Table 15. List of authoritative deflections on sections

\begin{tabular}{|c|c|c|c|c|c|c|c|c|c|c|c|}
\hline \multirow{2}{*}{ Section } & \multirow{2}{*}{ Roadway } & \multicolumn{7}{|c|}{ The average deflection under the geophone $[\mu \mathrm{m}]$} & \multicolumn{3}{|c|}{ Layers' modules [MPa] } \\
\hline & & w0 & w1 & w2 & w3 & w4 & w5 & w6 & E3 & E2 & E1 \\
\hline \multirow{2}{*}{$\begin{array}{c}\text { from } 27+525,00 \\
\text { to } 30+450,00\end{array}$} & Left & 589.3 & 492 & 382.6 & 308 & 267 & 218 & 176 & 1987.12 & 302.83 & 63.19 \\
\hline & Right & 610.2 & 489.8 & 375.3 & 308.9 & 246.7 & 170.7 & 131 & 1932.65 & 177.49 & 70.47 \\
\hline \multirow{2}{*}{$\begin{array}{c}\text { from } 31+275,00 \\
\text { to } 35+500,00\end{array}$} & Left & 730 & 594 & 515.7 & 397 & 310 & 224 & 180 & 1952.07 & 159.7 & 54.18 \\
\hline & Right & 766.5 & 605.3 & 463 & 382 & 294 & 190 & 140.1 & 1757.84 & 105.35 & 59.98 \\
\hline \multirow{2}{*}{$\begin{array}{c}\text { from } 35+850,00 \\
\text { to } 36+450,00\end{array}$} & Left & 784 & 646 & 523.9 & 410 & 303 & 249 & 190 & 1255.36 & 107.52 & 50.16 \\
\hline & Right & 759.3 & 623.4 & 493.2 & 402 & 329 & 248 & 202.6 & 1171.97 & 554.28 & 50.58 \\
\hline \multirow{2}{*}{$\begin{array}{c}\text { from } 36+625,00 \\
\text { to } 37+225,00\end{array}$} & Left & 524.9 & 459 & 366.1 & 298 & 255 & 218 & 169 & 3407.14 & 184.25 & 68.49 \\
\hline & Right & 560 & 444.1 & 347.9 & 302 & 225 & 165 & 134.9 & 2188.6 & 151.06 & 79.55 \\
\hline
\end{tabular}

Table 16. Technical data of the existing structure on sections

\begin{tabular}{|c|c|c|c|c|c|c|}
\hline \multirow{2}{*}{ Section } & \multirow{2}{*}{ Roadway } & \multicolumn{2}{|c|}{ Layer thickness $[\mathrm{m}]$} & \multicolumn{3}{|c|}{ Poisson's ratio } \\
\hline & & h3 & h2 & v3 & v2 & v1 \\
\hline \multirow{2}{*}{$\begin{array}{c}\text { from } 27+525,00 \\
\text { to } 30+450,00\end{array}$} & Left & 0.194 & 0.212 & 0.35 & 0.3 & 0.3 \\
\hline & Right & 0.194 & 0.212 & 0.35 & 0.2 & 0.3 \\
\hline \multirow{2}{*}{$\begin{array}{c}\text { from } 31+275,00 \\
\text { to } 35+500,00\end{array}$} & Left & 0.184 & 0.239 & 0.35 & 0.3 & 0.3 \\
\hline & Right & 0.184 & 0.239 & 0.35 & 0.3 & 0.3 \\
\hline \multirow{2}{*}{$\begin{array}{c}\text { from } 35+850,00 \\
\text { to } 36+450,00\end{array}$} & Left & 0.22 & 0.11 & 0.35 & 0.3 & 0.3 \\
\hline & Right & 0.22 & 0.11 & 0.35 & 0.3 & 0.3 \\
\hline \multirow{2}{*}{$\begin{array}{c}\text { from } 36+625,00 \\
\text { to } 37+225,00\end{array}$} & Left & 0.204 & 0.15 & 0.35 & 0.3 & 0.3 \\
\hline & Right & 0.204 & 0.15 & 0.35 & 0.3 & 0.3 \\
\hline
\end{tabular}

Note: the ground substrate is the clay sand or clay; geophones were spaced from the center of the load plate $-26.5,45,60,82.5,120$, and $144 \mathrm{~cm}$.

\section{Conclusion}

Analysis of the results obtained from the theoretical method and practical tests was performed. When comparing both methods and the results, the following conclusions were noted:

1. The most accurate results are always for the lowest layer for the 2, 3 and 4-layer models.

2. The closest to the correct set of modules is in the case of known deflections with an accuracy of $10^{-3} \mu \mathrm{m}$ and those with the smallest roundness. 
3. The largest deviations in relation to the correct module are when a set of deflections with the extreme points from the set is used.

4. It is possible to recognize the structure model by omitting the zero point and taking further into account.

5. A set of more results for a homogeneous section gives better possibilities of identifying modules due to the equalization of discrepancies and possible incorrect readings.

6. To determine the modules with the method, it is best to take the average reliable values after rejecting the extreme values based on the Chauvenet criterion.

7. The modulus of elasticity will be most likely for readings from geophones the closest to the FWD loading board.

\section{References}

[1] Nagórski R. Mechanika nawierzchni drogowych w zarysie. PWN, Warszawa 2014.

[2] Firlej S. Wyznaczanie parametrów modelu nawierzchni drogowej z dynamicznych badań FWD. Politechnika Lubelska 2015.

[3] Bajak M., Firlej S. Wykorzystanie metody ugięć do projektowania wzmocnień nawierzchni drogowych Drogownicwo 1 (2018) 22.

[4] Woszuk A., Firlej S. Metoda uwzględniania wartości ugięć poza zakresem nomogramu przy projektowaniu nawierzchni, Drogownictwo 10 (2013) 314-318.

[5] Bajak M., Firlej S. Wpływ rzeczywistego obciązenia na trwatość nawierzchni. Magazyn Autostrady 7 (2010) 56-59.

[6] Katalog Przebudów I Remontów Nawierzchni Podatnych i Półsztywnych GDDKiA Warszawa 2013.

[7] Chai G., Manoharan S., Golding A., Kelly G., Chowdhury S. Evaluation of the Traffic Speed Deflectometer data using simplified deflection model. $6^{\text {th }}$ Transport Research Arena, April 18-21 2016.

[8] Zofka A., Graczyk M., Rafa J., Qualitative evaluation of stochastic factors affecting the traffic speed deflectometer results. Transportation Research Board 94th Annual Meeting Washington DC 2015. 
